\title{
Production and dissolution of biosilica, and changing microphytoplankton dominance in the Bay of Brest (France)
}

\author{
C. Beucher ${ }^{1, *}$, P. Tréguer $^{1}$, R. Corvaisier ${ }^{1}$, A. M. Hapette ${ }^{1}$, M. Elskens $^{2}$ \\ ${ }^{1}$ Institut Universitaire Européen de la Mer, UMR 6539, Université de Bretagne Occidentale, Technopôle Brest-Iroise, \\ Place Nicolas Copernic, 29280 Plouzané, France \\ ${ }^{2}$ Department of Analytical and Environmental Chemistry, Vrije Universiteit Brussel, Pleinlaan 2, 1050 Brussels, Belgium
}

\begin{abstract}
This study presents (1) the first annual time-series recorded for any marine system of the weekly variability in rates of production $(P)$ and dissolution $(D)$ of biosilica $\left(\mathrm{BSiO}_{2}\right)$ and $(2)$ the first evidence of the end of the year-round dominance of diatoms in the Bay of Brest, a well-mixed anthropogenically nitrate-enriched macrotidal ecosystem, typical of western Europe. In coastal waters, silicic acid $\left(\mathrm{Si}(\mathrm{OH})_{4}\right)$ availability depends on both external inputs and internal recycling. We quantified the contribution of internal recycling through experiments conducted from April 2001 to April 2002 in the surface waters of SOMLIT-Brest station at the outlet of the bay. From spring to mid-summer, diatoms dominated successive microphytoplankton blooms and, since they require $\mathrm{Si}(\mathrm{OH})_{4}$ to construct their frustules, the concentration of $\mathrm{Si}(\mathrm{OH})_{4}$ in surface waters was severely reduced at this time, relative to winter (mean $1.62 \mu \mathrm{M}) ; \mathrm{BSiO}_{2}$ concentration and production and dissolution rates were high, averaging $1.26 \mu \mathrm{mol} \mathrm{l} \mathrm{l}^{-1}, 0.96 \mu \mathrm{mol} \mathrm{l}^{-1} \mathrm{~d}^{-1}$ and $0.40 \mu \mathrm{mol} \mathrm{l}^{-1} \mathrm{~d}^{-1}$, respectively. From mid-summer to mid-fall, non-siliceous phytoplankters predominated, and the mean surface-water concentration of $\mathrm{Si}(\mathrm{OH})_{4}$ was $4.67 \mu \mathrm{M}$. $\mathrm{BSiO}_{2}$ concentration and production and dissolution rates were low, averaging $0.69 \mu \mathrm{mol} \mathrm{l} \mathrm{l}^{-1}, 0.10 \mu \mathrm{mol} \mathrm{l^{-1 }} \mathrm{d}^{-1}$ and $0.04 \mu \mathrm{mol} \mathrm{l}^{-1} \mathrm{~d}^{-1}$, respectively. The summer shift from diatom to dinoflagellate dominance was likely under bottom-up control. The Bay of Brest, with $D: P$ ratios averaging 0.43 during the productive period, is intermediate between coastal upwelling systems, where new production usually predominates $(0.1<D: P<0.25)$, and oceanic oligotrophic systems, in which regenerated production usually predominates $(D: P \sim 1.0)$.
\end{abstract}

KEY WORDS: Coastal ecosystem · Time-series · Biosilica recycling · Phytoplankton dynamics Resale or republication not permitted without written consent of the publisher

\section{INTRODUCTION}

During the last decade, the role of diatoms in global marine primary production and in the export of organic matter has been confirmed (Nelson et al. 1995, Buesseler 1998). Diatoms are major contributors to primary production in oceanic regions (the Southern Ocean, e.g. Brzezinski et al. 2001; the eastern Equatorial Pacific, e.g. Dugdale \& Wilkerson 1998) and in coastal upwelling systems (e.g. Nelson et al. 1981, Brzezinski et al. 2003).

Silicic acid $\left(\mathrm{Si}(\mathrm{OH})_{4}\right)$ is an essential requirement in the formation of diatom frustules (Lewin 1961). Its availability in surface waters depends on both external inputs and internal recycling, and much research has been done to determine the contribution of the former (e.g. Tréguer et al. 1995, Conley 2002). However, we still know little about the exact contribution of internal recycling to $\mathrm{Si}(\mathrm{OH})_{4}$ availability in surface waters of different ecosystems on seasonal and annual timescales (Nelson et al. 1995, Tréguer et al. 1995), mainly because accurate determination of biosilica $\left(\mathrm{BSiO}_{2}\right)$ dissolution by mass spectrometry is still difficult to perform. Therefore, the magnitude of the dissolution rate:production rate ratio $(D: P)$ and its variability are not well defined; this constitutes one of the greatest 
remaining uncertainties of the global marine silica budget. More data are needed on the rate of dissolution of $\mathrm{BSiO}_{2}$ in the ocean, especially for coastal ecosystems.

The silica cycle in coastal ecosystems is now receiving much attention, because the long-term increase in anthropogenic inputs of dissolved inorganic nitrogen and phosphorus is changing the chemical composition of coastal waters (Howarth et al. 1996). This is reflected in the long-term decrease in $\mathrm{Si}(\mathrm{OH})_{4}$ :nitrate $(\mathrm{Si}: \mathrm{N})$ ratios, which can result in $\mathrm{Si}(\mathrm{OH})_{4}$ limitation (Officer \& Ryther 1980, Smayda 1990, Conley et al. 1993) and may favor drastic modifications to phytoplankton community structure (Revelante \& Gilmartin 1976, 1978, Billen et al. 1991, Fisher et al. 1992, Nelson \& Dortch 1996).

The Bay of Brest has been described as a macrotidal, well mixed system typical of western Europe (Delmas 1981). It is also representative among coastal ecosystems of this part of the world in respect of (1) the longterm change in the chemical composition of its waters due to anthropogenic influences (Le Pape et al. 1996) and (2) its exposure to large-scale phenomena from the North Atlantic Ocean (e.g. the North Atlantic Oscillation). Ragueneau et al. (1994) and Del Amo et al. $(1997 \mathrm{a}, \mathrm{b})$ suspected that $\mathrm{Si}(\mathrm{OH})_{4}$ limits the growth of diatoms after the first spring bloom in the nitrateenriched waters of the bay. Thus, it is critical to define the recycling of $\mathrm{Si}$ in order to predict and understand changes in phytoplankton dominance in this ecosystem. Although the recycling of $\mathrm{Si}(\mathrm{OH})_{4}$ at the sediment-water interface has already been quantified by Souchu (1986), Ragueneau et al. (1994), and Chauvaud et al. (2000), the recycling of Si in surface waters has never been measured. Moreover, neither seasonal variations in the $\mathrm{BSiO}_{2}$ production rate nor those of the dissolution rate have previously been discussed.

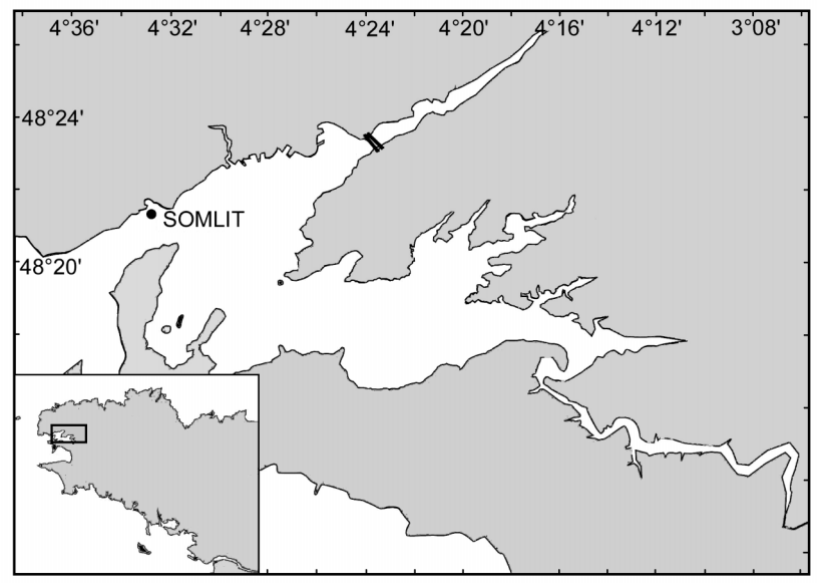

Fig. 1. SOMLIT-Brest station at the outlet of the Bay of Brest, France Western Europe
This study aims to describe and explain the silicon dynamics in surface waters of the Bay of Brest. Seasonal variations in $\mathrm{BSiO}_{2}$ concentration, the silica production rate and the silica dissolution rate, as well as the dynamics of micophytoplankton are described. The end of the year-round dominance of diatoms is discussed, in relation to changes in nutrient conditions and grazing pressure. The mechanisms that control the specific rate of dissolution of $\mathrm{BSiO}_{2}$ in the bay are also discussed. Finally, the average $D: P$ ratio during the productive period in the bay is compared to that of other ecosystems of the world ocean.

\section{MATERIALS AND METHODS}

Study site and sampling. This study was conducted at the SOMLIT-Brest station located at the outlet of the Bay of Brest (Fig. 1). This bay (mean depth $8 \mathrm{~m}$ ) is a productive coastal area fed by 2 small tributaries, the Aulne and Elorn rivers (average annual flow 21 and $5 \mathrm{~m}^{3} \mathrm{~s}^{-1}$, respectively). In spite of significant nutrient inputs from these rivers - with nitrate concentration peaking at 20 to $30 \mu \mathrm{M}$ during the salinity minium period (http://www.univ-brest.fr/IUEM/observation) the Bay of Brest waters remain typically marine throughout the year; the salinity varies little from 34 or 35 , except during short winter floods. The bay is connected to the Atlantic Ocean through a sound $1.8 \mathrm{~km}$ wide and $50 \mathrm{~m}$ deep. In this shallow macrotidal system (maximum tidal amplitude $8 \mathrm{~m}$, tide periodicity: $12 \mathrm{~h}$ $15 \mathrm{~min}$ and $14 \mathrm{~d}$, maximum tidal currents $2.6 \mathrm{~m} \mathrm{~s}^{-1}$ ), vertical and horizontal redistribution of suspended material is usually strong periodically, during spring tides, and/or aperiodically especially during fall and winter storms. Tidal currents and wind ensure that waters are well mixed. Over the last $25 \mathrm{yr}$, the increasing amounts of nitrate delivered to the bay have decreased the Si:N molar ratio from 0.5-0.6 in 1975 (Tréguer \& Le Corre 1976) to 0.3-0.4 today, reflecting the impact of about doubled nitrate riverine concentrations.

From April 2001 to April 2002, sampling was performed at $1 \mathrm{~m}$ depth every week during high tide, in mean tidal conditions. Seawater was collected using a Niskin bottle. All sampling material and bottles were acid pre-cleansed and rinsed with pure water.

Analytical procedures. Temperature and salinity were measured with a calibrated WTW CTD. $\mathrm{Si}(\mathrm{OH})_{4}$ and nitrate concentrations were determined (precision $\pm 0.1 \mu \mathrm{M}$ ) on a Technicon Autoanalyzer II (Tréguer \& Le Corre 1975). Phosphate concentration was measured using the method of Murphy \& Riley (1962) (precision $\pm 0.02 \mu \mathrm{M}$ ). For $\mathrm{BSiO}_{2}, 1 \mathrm{l}$ of seawater was filtered through Nuclepore polycarbonate membranes $(0.6 \mu \mathrm{m})$ using a plastic filter tower; the filter was dried 
at ambient temperature under a laminar flow hood, concentrations were determined after $\mathrm{NaOH}$ and $\mathrm{HF}$ digestions, successively. $\mathrm{BSiO}_{2}$ was corrected for lithogenic silica $\left(\mathrm{LSiO}_{2}\right)$ interference according to Ragueneau \& Tréguer (1994) (blank $=0.005 \mu \mathrm{mol} \mathrm{l}{ }^{-1}$, precision $\pm 10 \%$ ). $\mathrm{LSiO}_{2}$ determination (blank $=0.005 \mu \mathrm{mol}$ $\mathrm{l}^{-1}$, precision $\pm 10 \%$ ) was also done according to Ragueneau \& Tréguer (1994).

For the determination of chlorophyll a (chl a) and pheopigment, $1 \mathrm{l}$ of seawater was filtered onto Whatmann GF/F filters. The analysis was done according to Yentsch \& Menzel (1963) using a calibrated Turner 111 fluorometer (precision $\pm 0.1 \mu \mathrm{gl}^{-1}$ ). Surface water samples for phytoplankton species determination were preserved in Lugol's solution. Species were identified and counted by examination on an inverted microscope according to Utermöhl (1931), between 100 (precision $\pm 20 \%$, Lund et al. 1958) and 1500 cells (precision $5 \%$ ) were identified per sample.

$\mathrm{BSiO}_{2}$ production and dissolution rates were measured in the same sample (i.e. strictly the same incubation, temperature, and volume conditions) using the ${ }^{30} \mathrm{Si}$ stable isotope as a tracer. Samples were incubated for $24 \mathrm{~h}$ in a Plexiglas incubator under natural sunlight in flowing seawater to maintain surface water temperature. The method used was quite similar to that developed by Nelson \& Goering $(1977 \mathrm{a}, \mathrm{b})$; the sample was spiked by ${ }^{30} \mathrm{Si}(\mathrm{OH})_{4}$ so that the increase in in situ concentration did not exceed $10 \%$. The improvement offered by our method lies in the direct measurement of $\mathrm{SiO}_{2}^{-}$(and not $\mathrm{SiF}_{3}^{+}$), making void the use of hazardous HF. To determine isotopic abundances, we used a THQ Finnigan mass spectrometer. For detailed chemical and analytical procedures, see R. Corvaisier, P. Tréguer, C. Beucher, M. Elskens (unpubl.) The precision of $\rho_{P}$ (the absolute silica production rate in $\mu \mathrm{mol}$ $\mathrm{l}^{-1} \mathrm{~d}^{-1}$ ) was calculated on 8 replicates (8 incubations of the same water). The SD corresponded to $0.02 \mu \mathrm{mol}$ $\mathrm{l}^{-1} \mathrm{~d}^{-1}$, and the detection limit was estimated at 3SD = $0.06 \mu \mathrm{mol} \mathrm{l} \mathrm{l}^{-1} \mathrm{~d}^{-1}$. Similarly, the SD of $\rho_{D}$ (the absolute silica dissolution rate in $\mu \mathrm{mol} \mathrm{l^{-1 }} \mathrm{d}^{-1}$ ) was $0.014 \mu \mathrm{mol}$ $\mathrm{l}^{-1} \mathrm{~d}^{-1}$ and the detection limit $0.042 \mu \mathrm{mol} \mathrm{l}^{-1} \mathrm{~d}^{-1}$.

Calculation of production and dissolution rates. In contrast to previous methods (e.g. Nelson \& Goering $1977 \mathrm{a}, \mathrm{b})$, the $\mathrm{BSiO}_{2}$ production and dissolution rates were herein constrained by the requirement to fit mass and isotopic balances, the best solution being found iteratively (Elskens et al. 2002). A diagrammatic representation of the model used to describe Si cycling in a tracer enrichment experiment is shown below. Important features of the model are that all the Si that leaves the dissolved phase is assumed to appear as particulate $\mathrm{BSiO}_{2}$, and that $\mathrm{Si}$ recycling is regarded as a process that transfers Si from the particulate to the dissolved pool:

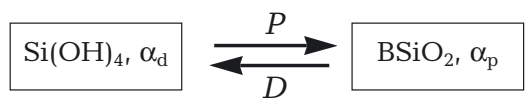

where $\mathrm{Si}(\mathrm{OH})_{4}$ and $\mathrm{BSiO}_{2}$ and $\alpha_{\mathrm{d}}$ and $\alpha_{\mathrm{p}}$ are the concentrations and isotopic enrichments in the dissolved and particulate phase, respectively; and $P$ and $D$ denote the production and the dissolution rates, respectively.

Straightforward integration of the differential equations corresponding to the above model yields the following analytical solutions for Si concentrations and isotopic enrichments:

$\mathrm{Si}(\mathrm{OH})_{4, t}=\mathrm{Si}(\mathrm{OH})_{4,0}+(D-P) \cdot t$

$\alpha_{\mathrm{d}, t}=\alpha_{\mathrm{p}, 0}+\left(\alpha_{\mathrm{d}, 0}-\alpha_{\mathrm{p}, 0}\right) \cdot\left(1+\frac{D-P}{\mathrm{Si}(\mathrm{OH})_{4,0}} \cdot t\right)^{\frac{D}{P-D}}$

$\mathrm{BSiO}_{2, t}=\mathrm{BSiO}_{2,0}+(P-D) \cdot t$

$\alpha_{\mathrm{p}, t}=\alpha_{\mathrm{p}, 0}+\frac{\mathrm{Si}(\mathrm{OH})_{4,0} \cdot\left(\alpha_{\mathrm{d}, 0}-\alpha_{\mathrm{p}, 0}\right)}{\mathrm{BSiO}_{2,0}+(P-D) \cdot t} \cdot\left(1-\left(1+\frac{D-P}{\mathrm{Si}(\mathrm{OH})_{4,0}} \cdot t\right)^{\frac{D}{P-D}}\right)$

where indices 0 and $t$ denote the initial and final times of the incubation period.

Production and dissolution rates $(P, D)$ are estimated with an inverse least-squares technique, and the uncertainty analysis of the least-squares estimation is performed with Monte-Carlo simulations according to Elskens et al. (2002). $\rho_{P}$ and $\rho_{D}$ see section 'Analytical procedures' for definitions) are equal to $P$ and $D$, respectively.

In order to validate the calculations of $\rho_{P}$ and $\rho_{D}$, we calculated the mass balance on $\mathrm{Si}(\mathrm{OH})_{4}$ in each incubated bottle using the data extracted from the model and the concentrations of $\mathrm{Si}(\mathrm{OH})_{4}$ measured in 3 replicates (precision $0.04 \mu \mathrm{M}$ ). $\Delta t$ being the time of incubation, the values of $\left[\mathrm{Si}(\mathrm{OH})_{4 \text { final }}\right]$ were plotted versus $\left[\mathrm{Si}(\mathrm{OH})_{4 \text { initial }}-\rho_{P} \times \Delta t+\rho_{D} \times \Delta t\right]$ (Fig. 2). The data $(\mathrm{n}=48)$ are linearly correlated $\left(\mathrm{R}^{2}=0.998\right)$ and the slope (1.01) is very close to 1 as expected.

\section{RESULTS}

\section{Physical, chemical and biological parameters}

Table 1 summarizes seasonal variations in chemical and biological parameters measured during this study. The variation in temperature and salinity in surface waters versus time are shown in Fig. 3a. In accordance with previous studies (Quéguiner 1982, Ragueneau et al. 1994, Del Amo et al. 1997a), we found that the temperature gradually increased from April to August (maximum $18^{\circ} \mathrm{C}$ on August 16 and 31, 2001), de- 
creased to $8.8^{\circ} \mathrm{C}$ in the middle of January 2002, and then began to increase again. The salinity increased from 33.9 in early spring to 34.8 in June 2001; it then remained almost constant (between 34.8 and 35.4) from June 2001 to January 18, 2002, and decreased to a minimum of 33.9 in February 2002 before the typical spring increase. The seasonal variation in salinity was less pronounced than in previous studies (e.g. Del Amo et al. 1997a), because of lower riverine inputs during our study period. Daily solar radiation (data not presented here) followed the seasonal evolution of temperate areas. Lowest values were observed in winter $\left(<550 \mathrm{~J} \mathrm{~cm}^{-2} \mathrm{~d}^{-1}\right)$ while the summer maximum reached $3000 \mathrm{~J} \mathrm{~cm}^{-2} \mathrm{~d}^{-1}$. From April to mid-October 2001 the irradiance was usually sufficient $\left(>1000 \mathrm{~J} \mathrm{~cm}^{-2} \mathrm{~d}^{-1}\right)$ to sustain photosynthetic activity in surface waters (Quéguiner \& Tréguer 1984). Occasionally, however, during summer 2001 the solar radiation decreased to values as low as $550 \mathrm{~J} \mathrm{~cm}^{-2} \mathrm{~d}^{-1}$.

Temporal variation in nutrients reflects the concurrent impact of (1) freshwater nutrient-rich inputs, (2) exchanges with the nutrient-poor Iroise sea (Atlantic Ocean), (3) phytoplankton uptake and (4) nutrient recycling (that occur both in the water column and at the sediment-water interface). Nitrate concentrations (Fig. 3b) ranged from 0.1 to $23.6 \mu \mathrm{M}$, and were $<1 \mu \mathrm{M}$ from June to September 2001. DIN $\left(\mathrm{NO}_{3}+\mathrm{NO}_{2}+\mathrm{NH}_{4}\right)$ (Fig. 3b) ranged from 0.45 to $24.61 \mu \mathrm{M}$, with concentrations $<2 \mu \mathrm{M}$ from June 1 to October 1, i.e. levels considered as limiting for phytoplankton growth (Del Amo et al. 1997a). Phosphate concentrations (details at http://www.univ-brest.fr/IUEM/observation/ observation_iroise.htm) ranged from 0 to $0.55 \mu \mathrm{M}$, with values $<0.15 \mu \mathrm{M}$ from mid-April to September 2001. Since Del Amo et al. (1997a) consider that phosphate

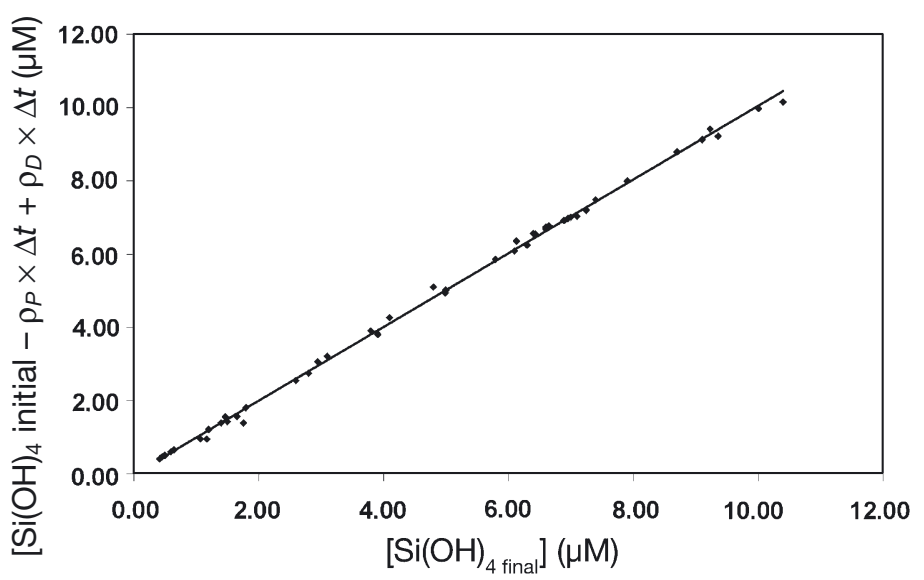

Fig. 2. Mass balance on $\mathrm{Si}(\mathrm{OH})_{4}$ for each incubated sample $(\mu \mathrm{M}):\left[\mathrm{Si}(\mathrm{OH})_{4 \text { final }}\right]=\left[\mathrm{Si}(\mathrm{OH})_{4 \text { initial }}\right]+\left(\rho_{D}-\rho_{P}\right) \times \Delta t$. Si $(\mathrm{OH})_{4}$ final and initial concentrations are measured with a precision of $0.04 \mu \mathrm{M}, \rho_{P}$ and $\rho_{D}$ are estimated by the model $\mathrm{y}=1.01 \mathrm{x}-0.03$ $\left(\mathrm{n}=48, \mathrm{R}^{2}=0.998\right)$
Table 1. Seasonal means of chemical and biological parameters in the Bay of Brest (2001 to 2002). DIN represents the sum of nitrate, nitrite and ammonium, $D: P$ is the ratio of the time-integrated silica dissolution rate $\left(\rho_{D}\right)$ to the timeintegrated silica production rate $\left(\rho_{P}\right)$ over the season or the year. $\mathrm{BSiO}_{2}=$ biosilica, $\mathrm{LSiO}_{2}=$ lithogenic silica $V_{P}$ and $V_{D}$ are specific silica production and dissolution rates, respectively

\begin{tabular}{|c|c|c|c|c|c|}
\hline & Spring & Summer & Fall & Winter & Annual \\
\hline Chl a $\left(\mu g l^{-1}\right)$ & 2.6 & 2.01 & 1.16 & 1.07 & 1.75 \\
\hline $\begin{array}{l}\text { Pheopigment } \\
\left(\mu \mathrm{g} \mathrm{l}^{-1}\right)\end{array}$ & 1.6 & 1.54 & 1.12 & 1.43 & 1.41 \\
\hline $\mathrm{NO}_{3}^{-}(\mu \mathrm{M})$ & 6.5 & 0.4 & 4.6 & 16.9 & 6.6 \\
\hline DIN $(\mu \mathrm{M})$ & 7.3 & 1.1 & 6.4 & 18.1 & 7.8 \\
\hline $\mathrm{PO}_{4}{ }^{3-}(\mu \mathrm{M})$ & 0.1 & 0.09 & 0.34 & 0.48 & 0.25 \\
\hline $\mathrm{Si}(\mathrm{OH})_{4}(\mu \mathrm{M})$ & 1.9 & 2.8 & 5.8 & 7.7 & 4.44 \\
\hline $\mathrm{BSiO}_{2}\left(\mu \mathrm{mol} \mathrm{l}^{-1}\right)$ & 1.2 & 0.9 & 0.8 & 0.6 & 0.9 \\
\hline $\mathrm{LSiO}_{2}\left(\mu \mathrm{mol} \mathrm{l} l^{-1}\right)$ & 2.7 & 1.6 & 0.7 & 17.5 & 5 \\
\hline$\rho_{P}\left(\mu \mathrm{mol} \mathrm{l}^{-1} \mathrm{~d}^{-1}\right)$ & 0.57 & 0.77 & 0.06 & 0.15 & 0.40 \\
\hline$V_{P}\left(\mathrm{~d}^{-1}\right)$ & 0.49 & 0.73 & 0.09 & 0.30 & 0.40 \\
\hline$\rho_{D}\left(\mu \mathrm{mol} \mathrm{l} \mathrm{l}^{-1} \mathrm{~d}^{-1}\right)$ & 0.18 & 0.36 & 0.05 & 0.09 & 0.17 \\
\hline$V_{D}\left(\mathrm{~d}^{-1}\right)$ & 0.16 & 0.37 & 0.07 & 0.22 & 0.20 \\
\hline$D: P$ & 0.37 & 0.45 & 0.81 & 0.63 & 0.45 \\
\hline
\end{tabular}

concentrations $\leq 0.2 \mu \mathrm{mol} \mathrm{l}^{-1}$ in the Bay of Brest are limiting for phytoplankton growth, phosphate was limiting throughout the productive period and even until the end of summer. $\mathrm{Si}(\mathrm{OH})_{4}$ concentrations (Fig. 3b) ranged from 0.65 to $9.7 \mu \mathrm{M}$. However, during the productive period (spring-summer), the concentration remained below $2 \mu \mathrm{M}$-i.e. at limiting concentration for the growth of diatoms in the study site, according to Del Amo et al. (1997a) - except on June 27 and July 10. The $\mathrm{Si}(\mathrm{OH})_{4}$ concentration started to rise gradually from August 2001 to reach a maximum in February 2002, coinciding with the riverine impact maximum (salinity minimum) in the Bay of Brest.

Chl a (Fig. 3c) ranged from 0.49 to $5.76 \mu \mathrm{g} \mathrm{l}^{-1}$, with a mean annual value of $1.75 \mathrm{\mu g} \mathrm{l}^{-1}$. As observed to previous studies (Quéguiner 1982, Ragueneau et al. 1994, Del Amo et al. 1997a, Savoye 2001), successive blooms occurred from spring to mid-autumn 2001. The first spring bloom showed the highest concentration of chl a $\left(5.76 \mu \mathrm{g} \mathrm{l}^{-1}\right)$, preceding a succession of medium inten-

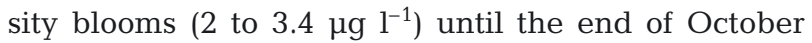
2001. From November 2001 to February 2002, the concentration of chl a remained low (mean $0.7 \mu \mathrm{g} \mathrm{l}^{-1}$ ) and began to increase again at the beginning of spring. During the first bloom of chl a (May 2001), and until the end of July 2001, pheopigment concentration remained quite low (ca. $1 \mathrm{\mu g} \mathrm{l}^{-1}$ ) (Fig. 3c). On the contrary, from August to October 2001, relatively high concentrations of pheopigment (mean $1.8 \mu \mathrm{g} \mathrm{l}^{-1}$ ) were measured. From November 2001 to January 2002, pheopigment concentration remained low again (mean $0.7 \mu \mathrm{g} \mathrm{l}^{-1}$ ), but started to increase after mid-January 2002. 

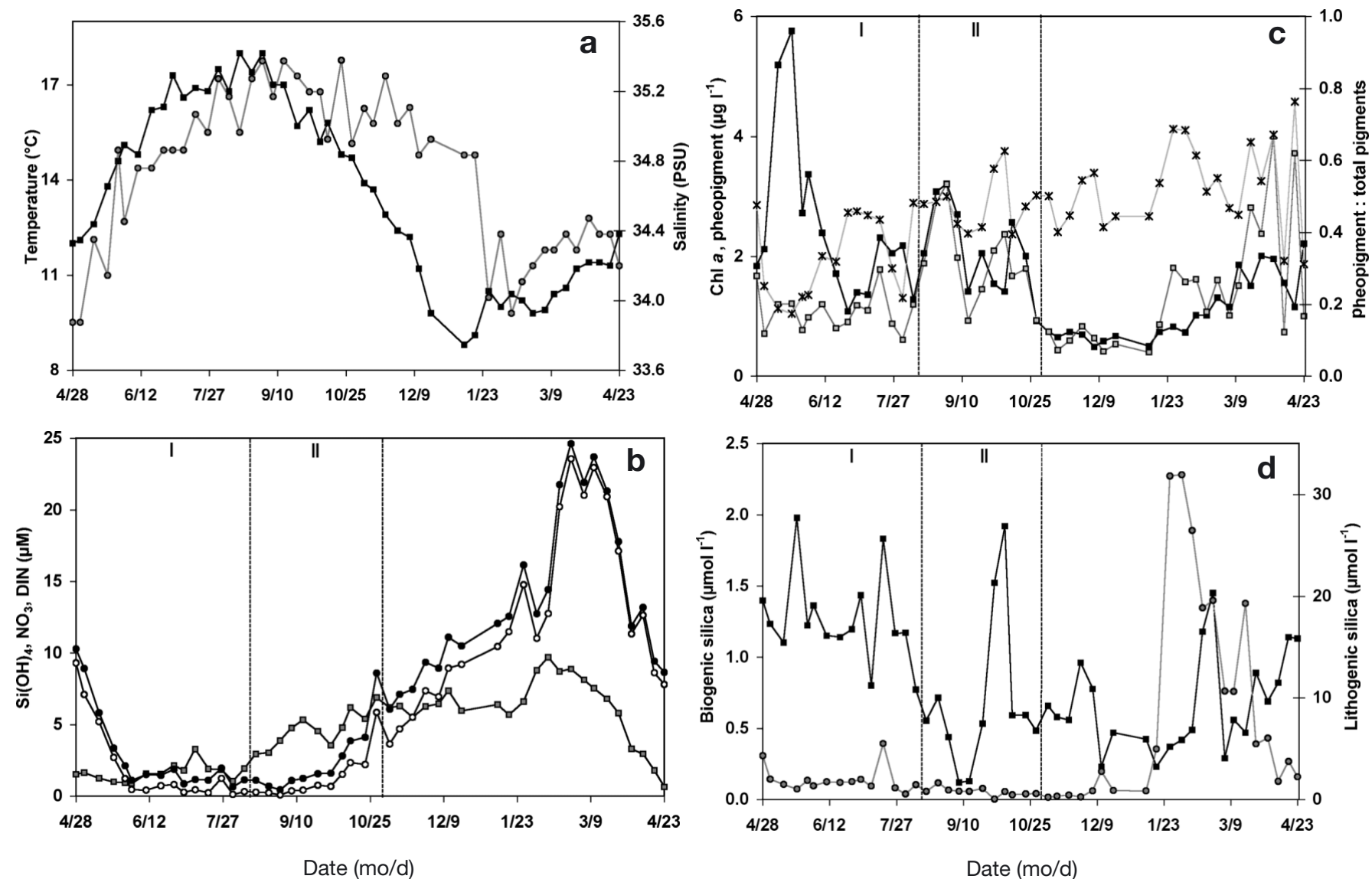

Fig. 3. Time series at the SOMLIT-Brest station (April 2001 to April 2002). (a) Temperature $\left({ }^{\circ} \mathrm{C}_{1}-\square-\right)$ and salinity (PSU, $\left.-\circ-\right)$. (b) Nitrate (-o-), DIN $\left(\mathrm{NO}_{3}{ }^{-}+\mathrm{NO}_{2}{ }^{-}+\mathrm{NH}_{4}{ }^{+}\right)(-\bullet-)$ and silicic acid $(-\square-, \mu \mathrm{M})$. (c) Chl a $\left(-\square_{-}, \mu g \mathrm{l}^{-1}\right)$, pheopigment $\left(-\square-, \mu g \mathrm{l}^{-1}\right)$ and ratio of pheopigment to total pigments $(-\mathbf{x}-)$. (d) Biogenic $(--)$ and lithogenic $(-\circ-)$ silica concentration $\left(\mu m o l l^{-1}\right)$. I: Period I; II: Period II

The specific composition of microphytoplankton (Fig. 4) showed a 2-period pattern. Diatoms predominated during Period I (April 28, 2001 to August 9, 2001). During Period II (August 16, 2001 to October 29, 2001), the microphytoplankton predominance switched to nonsiliceous species (Fig. 4). During Period I, 3 major blooms occurred, peaking on May 21 (83\% Rhizosolenia delicatula, mean size 20 to $40 \mu \mathrm{m})$, July $3(76 \%$ Chaetoceros sp., $10 \mu \mathrm{m}$ ) and August 2 (38\% R. delicatula and $44 \%$ Nitzchia sp., 45 to $95 \mu \mathrm{m})$. Diatoms were mainly living cells (mean: 84\%). During Period II, diatoms were principally Nitzchia closterium (40 to $45 \mu \mathrm{m}$ ), Nitzchia sp. and $R$. delicatula; dead diatoms averaged $36 \%$. Dinoflagellates were dominated $(>90 \%$ ) by a unique species Gymnodinium chlorophorum. For the rest of

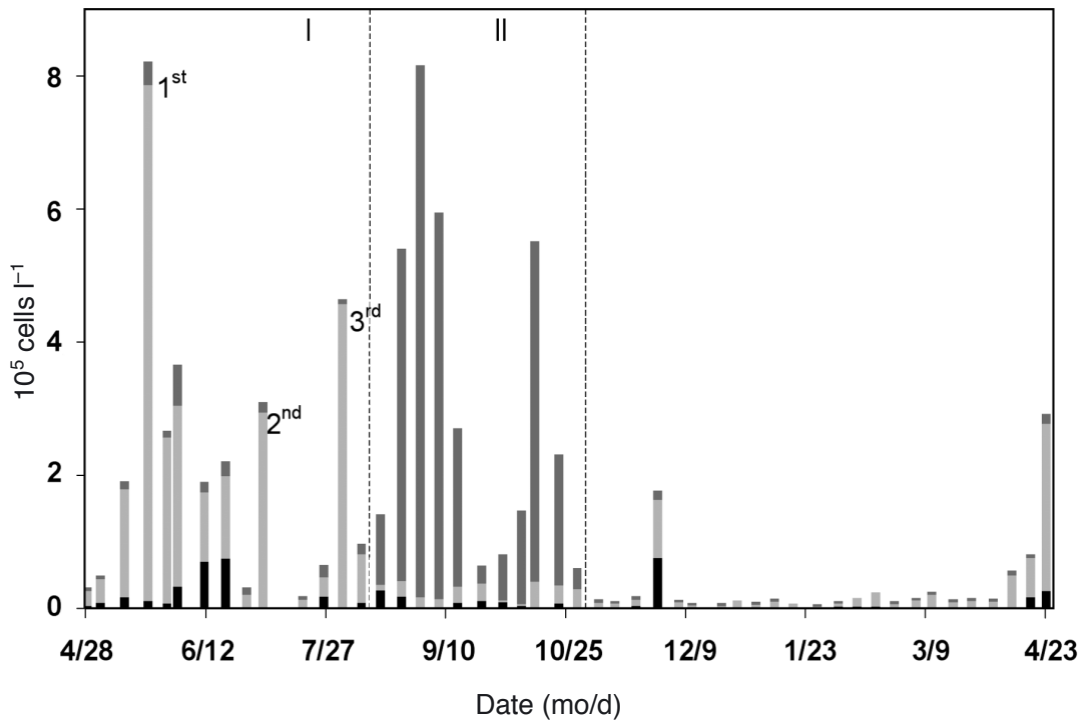

Fig. 4. Time series at the SOMLIT-Brest station (April 2001 to April 2002) showing the specific composition of phytoplankton: dead diatoms (black), living diatoms (light grey) and dinoflagellates (dark grey) (cells l $^{-1}$ ) 

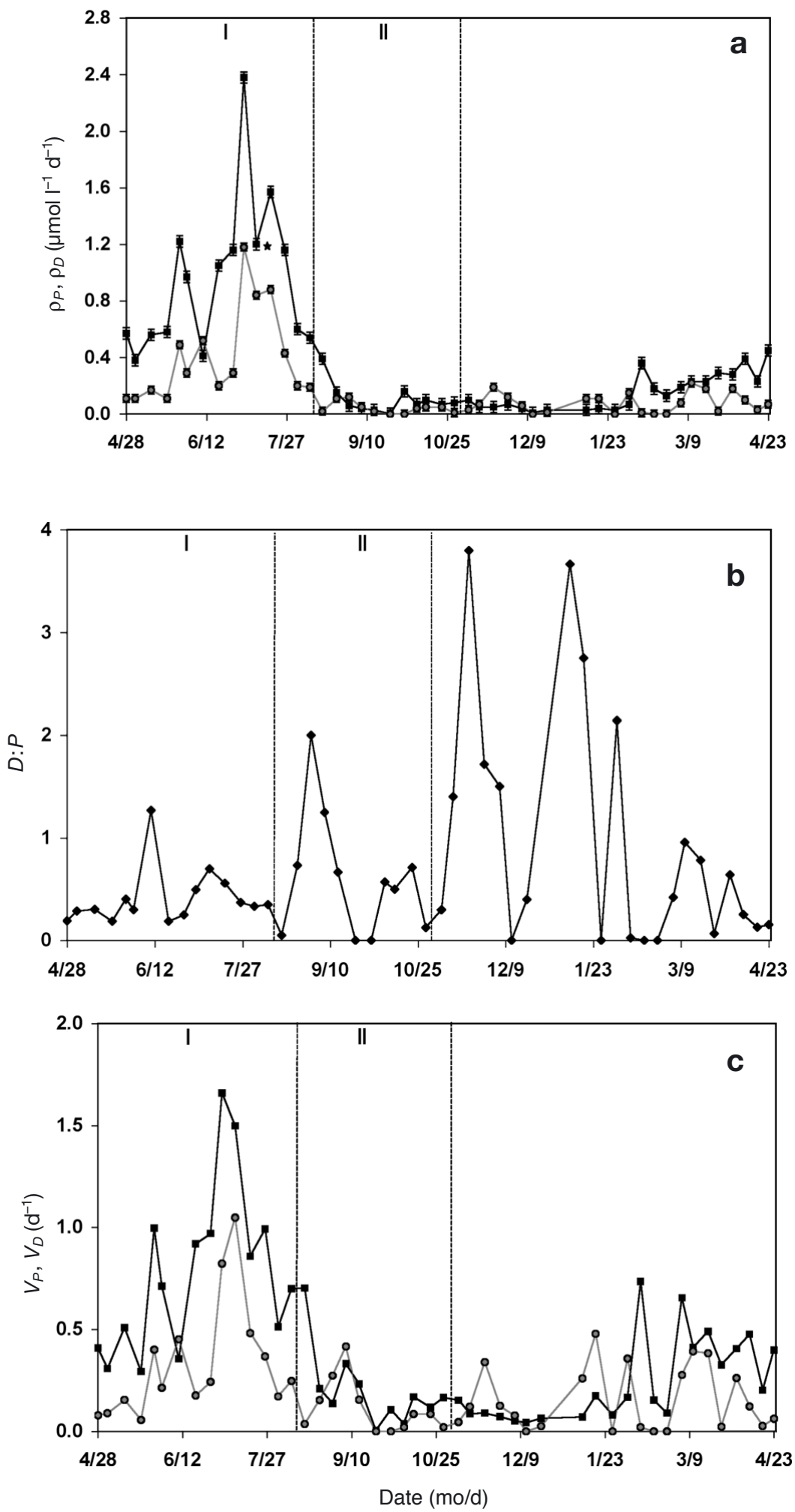

Fig. 5. Time-series at the SOMLIT-Brest station (April 2001 to April 2002) showing (a) absolute rate of biogenic silica production (- - - ) and dissolu-

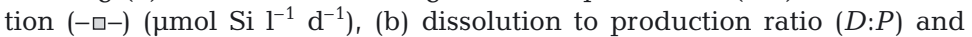
(c) specific production (--) and dissolution $\left(-{ }^{-}\right)$rates $\left(\mathrm{d}^{-1}\right)$. Error bars in (a) correspond to 2 SD. I: Period I; II: Period II the year, microphytoplankton was dominated by $N$. closterium and by a tiny bloom of Thalassosira sp. on November 11.

The $\mathrm{BSiO}_{2}$ concentration (Fig. 3d) ranged from 0.12 to $1.98 \mu \mathrm{mol} \mathrm{l}^{-1}$ (annual mean $0.9 \mathrm{mmol} \mathrm{l}^{-1}$ ). In the first spring bloom of 2001, $\mathrm{BSiO}_{2}$ peaked at $1.98 \mu \mathrm{mol} \mathrm{l}{ }^{-1}$, comparable to that of spring $1992\left(1.8 \mu \mathrm{mol} \mathrm{l^{-1 }}\right.$, Ragueneau et al. 1994) and lower than that of spring $1993\left(2.5 \mathrm{\mu mol} \mathrm{l}^{-1}\right.$, Del Amo et al. 1997b). $\mathrm{BSiO}_{2}$ concentration also peaked on July 18. During Periods I and II, mean val-

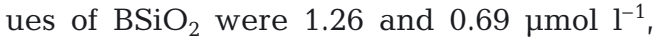
respectively. In the latter period, a significant part of the measured $\mathrm{BSiO}_{2}$ was detrital (dead diatoms). Specifically, on August 16 and October 1, the contributions of diatoms to the total microphytoplankton abundance were 25 and $17 \%$, respectively, but most of the diatom cells were dead (79 and $75 \%$, respectively); thus, the respective $\mathrm{BSiO}_{2}$ concentrations (0.56 and $1.52 \mu \mathrm{mol}$ $\mathrm{l}^{-1}$ ) were mainly due to detrital silica.

$\mathrm{LSiO}_{2}$ concentrations (Fig. 3d) varied from 0.06 to $31.94 \mu \mathrm{mol} \mathrm{l}^{-1}$, remaining quite low, except in winter 2002. The high values (>5 $\mu \mathrm{mol} \mathrm{l}^{-1}$ from mid-January to the end of March) mostly reflected the resuspension of sedimented lithogenic material at the sediment-water interface due to strong wind mixing. $\mathrm{LSiO}_{2}$ also peaked on July 18. From January 27 to March 19, $\mathrm{LSiO}_{2}$ concentrations reached maxima $\left(32,20,19 \mu \mathrm{mol} \mathrm{l} \mathrm{l}^{-1}\right)$ coinciding with high wind speeds (10.3, 8.4, $8.8 \mathrm{~m} \mathrm{~s}^{-1}$ ).

During Period $\mathrm{I}_{1} \mathrm{BSiO}_{2}$ concentration was poorly correlated to the concentration of total pigments $-\mathrm{BSiO}_{2}=0.12 \times(\mathrm{chl} a+$ pheopigment $)+0.82\left(\mathrm{~N}=15, \mathrm{R}^{2}=0.32\right)-$ suggesting that diatoms, although dominant, were not the only contributors to microphytoplankton biomass. However, when diatoms contributed $>85 \%$ the total microphytoplankton abundance, $\mathrm{BSiO}_{2}$ was significantly correlated to chl $a-\mathrm{BSiO}_{2}=$ $0.23 \times \mathrm{chl} a+0.67\left(\mathrm{~N}=6, \mathrm{R}^{2}=0.82\right)$-indicating that most of the $\mathrm{BSiO}_{2}$ was non-detrital silica. Variation in $\mathrm{BSiO}_{2}$ concentration can be an indicator of diatom species composition: $\mathrm{BSiO}_{2}$ peaked on October 1 and 8, unlike chl $a$, revealing the presence of Coscinodiscus spp. which are large and highly silicified species (Brzezinski 1985). It can also reflect variable physical conditions: the July 18 peak, concomitant with a peak of 
$\mathrm{LSiO}_{2}$, was probably due to the resuspension of sedimented diatoms (from July 3 bloom) due to strong wind conditions ( 6.7 and $5.2 \mathrm{~m} \mathrm{~s}^{-1}$ on July 17 and 18, respectively). In the same way, $\mathrm{LSiO}_{2}$ and pheopigment concentrations peaked on January 27, indicating a strong resuspension of material due to strong wind conditions (11.1 and $10.3 \mathrm{~m} \mathrm{~s}^{-1}$ on January 26 and 27, respectively).

\section{Silica production and dissolution rates}

$\mathrm{BSiO}_{2}$ production $\left(\rho_{P}\right)$ rates ranged from 0.002 to $2.38 \mu \mathrm{mol} \mathrm{l} \mathrm{l}^{-1} \mathrm{~d}^{-1}$, with an annual mean of $0.40 \mu \mathrm{mol}$ $\mathrm{l}^{-1} \mathrm{~d}^{-1}$ (Fig. 5a); the seasonal means were 0.57, 0.77, 0.06 and $0.15 \mu \mathrm{mol} \mathrm{l}^{-1} \mathrm{~d}^{-1}$ for spring, summer, fall, and winter, respectively. $\mathrm{BSiO}_{2}$ dissolution $\left(\rho_{D}\right)$ rates ranged from 0 to $1.18 \mu \mathrm{mol} \mathrm{l}^{-1} \mathrm{~d}^{-1}$ with an annual mean of $0.17 \mu \mathrm{mol} \mathrm{l^{-1 }} \mathrm{d}^{-1}$ (Fig. 5a); the seasonal means were $0.18,0.36,0.05$ and $0.09 \mu \mathrm{mol} \mathrm{l}^{-1} \mathrm{~d}^{-1}$ for spring, summer, fall, and winter, respectively. During Period I, the production rate peaked (Fig. 5a) on May 28, (1.22 $\left.\mathrm{umol} \mathrm{l}^{-1} \mathrm{~d}^{-1}\right)$, July 3 (2.38), and July 18 (1.57), generally concomitant with $\mathrm{BSiO}_{2}$ peaks (Fig. 3d). Simultaneously, the dissolution of $\mathrm{BSiO}_{2}$ in surface water was also active (Fig. 5), peaking on May

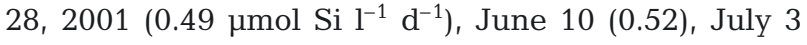
(1.18), and July $18(0.88)$. The absolute dissolution rate was lower than the production rate. Nevertheless, the $\mathrm{Si}(\mathrm{OH})_{4}$ concentration in surface waters, although severely depleted compared to that at the beginning of spring ( 8 to $10 \mu \mathrm{M}$ ), was never totally exhausted and remained $>0.9 \mu \mathrm{M}$. This indicates that processes other than the pelagic dissolution of $\mathrm{BSiO}_{2}$ were efficient in inputting and/or renewing the $\mathrm{Si}(\mathrm{OH})_{4}$ potential of the Bay of Brest surface waters (see Ragueneau et al. 1994, 2002). Complementary to the 2001 observations, the January-April 2002 data showed that the productive period can begin as early as the second fortnight of February. This is in accordance with previous studies (Quéguiner 1982, Ragueneau et al. 1994) which report occurrence of the first phytoplankton (diatom dominated) bloom, as soon as the surface water temperature is $>10^{\circ} \mathrm{C}$ and the surface irradiance $>1000 \mathrm{~J} \mathrm{~cm}^{-2} \mathrm{~d}^{-1}$. During Period II, in spite of higher concentrations in $\mathrm{Si}(\mathrm{OH})_{4}$ (Fig. 3b), diatoms were not predominant. The production and the dissolution of $\mathrm{BSiO}_{2}$ were considerably lower than during Period I (Fig. 5a): the mean production and dissolution rates were 0.1 and $0.04 \mu \mathrm{mol} \mathrm{l}^{-1} \mathrm{~d}^{-1}$, respectively for Period II, and 0.96 and $0.40 \mu \mathrm{mol} \mathrm{l}^{-1}$ $\mathrm{d}^{-1}$, respectively for Period I.

The ratio of the dissolution to production rate $\left(\rho_{D}: \rho_{P}\right.$ $=D: P$, Fig. $5 \mathrm{~b}$ ) ranged from 0 to 3.8. Annual integrated dissolution rate $\left(60.4 \mu \mathrm{mol} \mathrm{l}^{-1} \mathrm{yr}^{-1}\right)$ and pro- duction rate (133.3 $\left.\mu \mathrm{mol} \mathrm{l}^{-1} \mathrm{yr}^{-1}\right)$ gave an annual ratio of 0.45 . Seasonal integrated values for dissolution and production rates led to seasonal ratios of $0.37,0.45$, 0.81 and 0.63 , for spring, summer, fall and winter, respectively. In spring and summer, the in situ recycling was not efficient enough to cope with $\mathrm{Si}(\mathrm{OH})_{4}$ requirement for the pelagic production of $\mathrm{BSiO}_{2}$ (for a silica budget during spring, see Ragueneau et al. 1994). During Period I, the ratio (calculated using integrated production and dissolution rates) was 0.43 , but relatively high ratios occurred on June 10 (1.27) and from July 3 to $18(>0.5)$. The high ratio on June 10 can be explained by a strong decrease in the production rate that was probably due to a decrease in temperature and to nutrient limitations. The period from July 3 to 18 was characterized by the dominance of Chaetoceros sp. diatoms, which are typically small cells (mean size $10 \mu \mathrm{m}$ ). Small diatoms are known to remain in the water column longer than large ones, explaining the higher surface recycling efficiency during this period.

Estimates of the specific production rate $\left(V_{P}, \mathrm{~d}^{-1}\right)$ were calculated by dividing $\rho_{P}$ by the concentration of $\mathrm{BSiO}_{2}$. This specific rate ranged from 0.004 to $1.66 \mathrm{~d}^{-1}$ (mean annual rate $0.40 \mathrm{~d}^{-1}$ ) (Fig. 5b). Seasonal variations of $V_{P}$ usually followed those of $\rho_{P_{r}}$ with average rates of $0.49,0.73,0.09$, and $0.30 \mathrm{~d}^{-1}$ in spring, summer, fall, and winter, respectively. These $V_{P}$ values are actually underestimates of the specific rate because of the division by the total $\mathrm{BSiO}_{2}$. The analytical method used for the determination of $\mathrm{BSiO}_{2}$ gives the total $\mathrm{BSiO}_{2}$ concentration, i.e. it can not distinguish between living and detrital $\mathrm{BSiO}_{2}$. During Period I, living diatoms accounted for $84 \%$ of the total abundance on average (range 59 to $100 \%$ ). Taking this into account, to estimate the concentration of living $\mathrm{BSiO}_{2}$ is not trivial, especially in the case of mixtures of diatom taxa. The 2 highest specific production rates were observed (July 3, $1.66 \mathrm{~d}^{-1}$ and July 10, $1.5 \mathrm{~d}^{-1}$ ) for diatoms dominated by Chaetoceros $\mathrm{sp}$., the other maxima ranging around $1 \mathrm{~d}^{-1}$ for a heterogeneous population of diatoms.

Estimates of the specific dissolution rate $\left(V_{D}, \mathrm{~d}^{-1}\right)$ are calculated by dividing $\rho_{D}$ by the concentration of total $\mathrm{BSiO}_{2}$. The specific dissolution rate ranged from 0.00 to $1.05 \mathrm{~d}^{-1}$ with an annual mean value of $0.20 \mathrm{~d}^{-1}$ and seasonal means of $0.16,0.37,0.07$ and $0.22 \mathrm{~d}^{-1}$ for spring, summer, fall, and winter, respectively (Fig. 5b). Again, these values are underestimates of the specific rates as dead $\mathrm{BSiO}_{2}$ only is dissolvable (Lewin 1961). The 2 highest $V_{D}$ values were observed at the beginning of July when the diatom population was dominated by Chaetoceros sp., probably because of the specific characters of the frustule of this diatom species (surface area:volume ratio). 


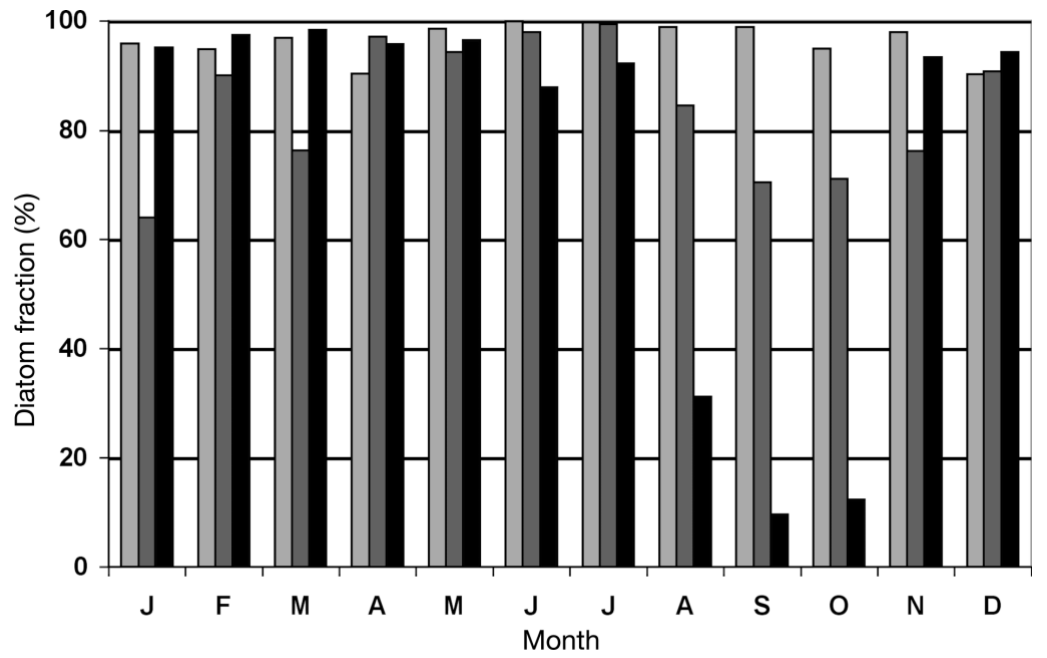

Fig. 6. Percentage of diatoms in microphytoplankton in 1981 (light grey) (Quéguiner 1982), 1993 to 1994 (dark grey) (Del Amo et al. 1997b) and in 2001 to 2002 (black) (this study)

\section{DISCUSSION}

\section{Towards the end of the year-round dominance of diatoms in the Bay of Brest?}

In the Bay of Brest, the long-term increase in anthropogenic nitrate enrichment from rivers has resulted in a 2-factor decrease in the Si:N molar ratio during winter (i.e. at the maximum freshwater discharge). Has this long-term continuing enrichment by riverine nitrate impacted the phytoplankton composition? Until now, there has been no indication of such an impact. Indeed, Quéguiner (1982) published the first extensive study on the species composition of phytoplankton of the Bay of Brest, showing that diatoms predominated in 1981 to 1982, whatever the season. About a decade later (1993 to 1994), Del Amo et al. (1997b) also established that, on an annual scale, the striking feature within the microphytoplankton community of the bay was the year-round dominance of diatoms over dinoflagellates. Thus, no significant change was obvious in the phytoplankton community structure, in spite of the long-term continuing enrichment of the Bay of Brest by riverine nitrate. A silicic acid pump, specific to well-mixed coastal ecosystems, was inferred by Del Amo et al. (1997b) and Ragueneau et al. (2002) to explain the maintenance of the dominance of diatoms during periods following the first spring bloom. Although intense blooms of non-siliceous species like Dinophysis sp. and/or of Gymnodinium sp. were occasionally reported during summer months (Chauvaud et al. 2000), they rapidly vanished. However, about $10 \mathrm{yr}$ later, the biosilica production was only active from spring to mid-summer 2001 (Fig. 5a), suggesting that diatoms might not be dominant throughout the year (Fig. 4).

Compared to 1981-1982 and 1993-1994, our study confirms that, from spring to the beginning of summer, diatoms remain predominant in the microphytoplankton (Fig. 6). This indicates that, in spite of increasing riverine deliveries of nitrate to the Bay of Brest over the last $20 \mathrm{yr}$, especially during winter, the recycling of $\mathrm{Si}(\mathrm{OH})_{4}$ (either at the sedimentwater interface [Ragueneau et al. 2002], and/or in the water column [this study, Fig. 5b]) remains sufficient to account for the Si requirement of diatoms. Inter-annual variations of the riverine nitrate deliveries to the Bay of Brest have been observed (details at http://www.univ-brest.fr/IUEM/observation/ ecoflux/ecoflux.htm) resulting from variable climatic conditions prevailing over western Europe during winter (North Atlantic Oscillation). High nitrate deliveries are associated with high precipitations of humid oceanic atmosphere flushed westward by strong winter winds, typical of the winter period in this region. Regardless of the climatic winter conditions during the last 2 decades, it seems that the microphytoplankton of the Bay of Brest has been able to cope with variable chemical environments to maintain diatom predominance, at least during spring.

Our study also shows that, in contrast to 1981 to 1982 and 1993 to 1994, the non-siliceous species (dinoflagellates) became predominant over diatoms from midsummer to fall 2001 (Fig. 6). This change might have taken place progressively over the last decade, as a summer decrease in diatom dominance was already evidenced in 1993. What triggered this drastic midsummer change in microphytoplankton dominance? It is beyond the scope of our paper to discuss the details of the inter-annual variability of the environmental conditions in the Bay of Brest with potential impacts on microphytoplankton species (C. Beucher et al. unpubl.), but we will here consider 2 major hypotheses.

First, it is remarkable that the switch from diatom to non-diatom dominance occurred during a $\mathrm{Si}(\mathrm{OH})_{4}$ rich period $\left(\mathrm{Si}\left(\mathrm{OH}_{4}\right)>2 \mu \mathrm{M}\right.$, Fig. 3b). According to Chauvaud et al. (2000), during summer and fall, intense sediment-water recycling is likely to support $\mathrm{Si}(\mathrm{OH})_{4}$ enrichment, while the in situ recycling in surface water contributes already 45 to $80 \%$ to the Si required for $\mathrm{BSiO}_{2}$ production (see our results). This clearly indicates that the $\mathrm{Si}(\mathrm{OH})_{4}$ availability is not the factor responsible for such a drastic biological change. Immediately after the first 2001 diatom bloom (May 21) 2 nutrient concentrations dropped to low values: $<0.1 \mu \mathrm{M}$ for phosphate, $<2 \mu \mathrm{M}$ for $\mathrm{Si}(\mathrm{OH})_{4}$, i.e. to values 
limiting for optimal diatom growth (Table 2). Diatoms are poor competitors at low phosphate concentrations (Malej et al. 1995, Riegman et al. 1996, Egge 1998). However, the growth of flagellates seems to be less affected by low nutrient concentrations, presumably because their motility favors nutrient encounter (Egge 1998). Although a second but moderate diatom bloom developed (peaking at $3 \times 10^{5}$ cells l$^{-1}$ on July 3 ), the severe co-limitation by $\mathrm{N}$ and $\mathrm{P}$ might explain why this bloom peaked at lower cell concentration than the first diatom bloom (Table 2). A third diatom bloom devel-

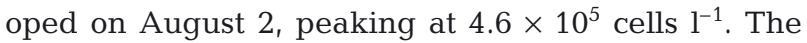
growth of this bloom was strongly limited as well by $\mathrm{N}$, $\mathrm{P}$ and Si (Table 2). After the collapse of the third bloom, the conditions seem to have been too unfavorable for diatoms. If so, and although other $\mathrm{N}$ sources (urea, aminoacids) and $\mathrm{P}$ sources (sediment, adsorption/ desorption on particles) were not measured, we can hypothesize that the summer 2001 switch from siliceous to non-siliceous species is explained by the ability of flagellates to tackle the poor inorganic nutrient conditions prevailing by the beginning of August. Interestingly, the 1993 scenario (year-round dominance of diatoms) differed from this 2001 scenario (dinoflagellates predominating over diatoms during summer and fall) in presenting less severe co-limitation conditions (Table 2). Similarly, the 1981 spring and summer blooms were characterized by diatom dominance and by weaker limitation conditions. The comparison between 1981, 1993 and 2001 suggests that a bottom-up process might have triggered the 2001 summer microphytoplankton dominance change.

Second, the role of grazers on phytoplankton community structure must also be taken into account. An indirect estimation of the total grazing pressure on phytoplankton, or at least of the impact of grazing on phytoplankton biomass, is provided by the relative variation in the ratio of pheopigment to total pigments. The 4 yr SOMLIT-Brest (http://www.univ-brest. fr/IUEM/observation/observation_iroise.htm) data set shows that the (pheopigment):(pheopigment $+\mathrm{chl}$ a) ratio annually averages 0.5 , suggesting that $50 \%$ of the phytoplankton biomass is grazed and/or biodegraded annually. During the spring phytoplankton bloom period, this ratio went through a typical minimum (0.2) (Fig. 3c); it then increased during late spring and summer, reaching a maximum (about 0.7) during fall and winter. Interestingly, a doubling of this grazing index (from 0.22 to 0.48 ) happened on August 9, i.e. just after the third diatom-dominated bloom (August 2). On August 9 , only $12 \%$ of diatoms were dead, the high concentration in pheopigment was therefore more likely representative of the grazed diatoms. This suggests that the collapse of the last 2001 diatom bloom, which occurred during unfavorable inorganic nutrient conditions (see above), was also favored by intense grazing of diatoms, especially by copepods (J. Le Fèvre pers. comm.). Except for one time-series showing the variation in the mesozooplankton biomass in the Bay of Brest during spring 1982 (Quéguiner 1982), no study is available on the seasonal and annual variations in pelagic grazers in our study are during the last 2 decades. Thus, we cannot know about a possible long-term shift in mesozooplankton populations (as observed by Beaugrand et al. 2002 in the North Atlantic Ocean), with more efficient grazing of diatoms by copepods in 2001 compared to 1981 and 1993. However, since the $\mathrm{BSiO}_{2}$-specific production rate $\left(V_{P}\right)$ remained low during Period II, grazing probably contributed little to the decrease in diatom biomass during this period.

Thus, the change in microphytoplankton dominance in the Bay of Brest that occurred during summer 2001 might have come from bottom-up or top-down processes, or both. While the facts to date are in support of bottom-up processes, the potential role of topdown processes - the selective role of pelagic grazers on phytoplankton community structure - is a question to be addressed in further studies.

\section{What controls the pelagic dissolution of biosilica in the Bay of Brest?}

Biogenic (amorphous) silica from naked diatom frustules is thermodynamically unstable in marine environments (Hurd \& Birdwhistell 1983), and tends to redissolve in $\mathrm{Si}(\mathrm{OH})_{4}$ as seawater is undersaturated with $\mathrm{Si}(\mathrm{OH})_{4}$ in 
every marine system (Hurd 1972). The dissolution rate increases with temperature (Kamatani \& Riley 1979, Kamatani 1982) and with the surface area of silica exposed to seawater (Hurd \& Birdwhistell 1983). It depends also on selective grazing and on diatom aggregation/desegregation (Dugdale et al. 1995, Nelson et al. 1995, Brzezinski et al. 1997, Dugdale \& Wilkerson 1998). The selective grazing can increase or decrease the dissolution rate, depending on the grazer. Some of them, by crunching diatoms, generate a lot of fragments that are easily dissolvable; others ingest entire diatoms and produce fecal pellets that trap $\mathrm{BSiO}_{2}$. Indirectly, the dissolution rate is also impacted by the physical conditions, as the resuspension of sedimented diatoms or fecal pellets containing $\mathrm{BSiO}_{2}$ may increase the dissolution rate measured in the water column. Following the work of Patrick \& Holding (1985), Bidle \& Azam (1999, 2001) and Bidle et al. (2003) have also demonstrated the role of bacterial protease activity in accelerating silica dissolution rate by removing the organic fraction of the cell wall which prevents direct contact between silica and seawater.

Before being involved in dissolution processes the $\mathrm{BSiO}_{2}$ produced in the surface waters of the bay undergoes different processes. A large part of the siliceous frustules of diatoms is grazed by zooplankton (mostly mesozooplankton) and/or by benthic filter feeders (Chauvaud et al. 2000), although grazing by ciliates, dinoflagellates, and bacteria have been reported (e.g. Buck et al. 1990, Bidle \& Azam 1999, Hamm et al. 2003). Grazing by pelagic or benthic organisms also generates detrital siliceous particles trapped by fecal pellets that settle to the bottom. When conditions are unfavorable for growth (for example, in cases of transient limitation by physical and/or chemical factors), diatoms (aggregated or not) rapidly settle on sediments. At the end of the first spring bloom, spectacular mass sedimentation of colonies of diatoms in the Bay of Brest is often reported by scuba divers (L. Chauvaud pers. comm.). Settlement of particulate matter is a process occurring on a time scale of hours or days. In non-turbulent conditions, the residence time of the suspended matter in the water column is short. However, the material falling in the water column, deposited at the sediment-water interface or rejected by benthic filter feeders is redistributed inside the water column both vertically by tidal stirring and/or wind mixing, and horizontally by tidal currents. Thus, the detrital component of a given surface water sample, although analytically indistinguishable from the living component, is not necessarily linked to this living component because of different dynamics with specific time scales.

In the Bay of Brest, $\rho_{D}$ was significantly correlated to $\rho_{P}\left(\mathrm{R}^{2}=0.7, \mathrm{~N}=15\right)$ during Period I, suggesting that, during the productive period, the source flux of dis- solving $\mathrm{BSiO}_{2}$ was mainly supported by production in surface waters. However, during Period II, there was no significant correlation between the 2 rates, showing that dissolution and production were uncoupled and/or that the flux of dissolving siliceous material mainly came from other sources than surface waters. From December to March, resuspension was the main source of dissolving silica, when $D: P$ was usually $>1$ and bottom resuspension (as evidenced by $\mathrm{LSiO}_{2}$ in the surface water) was greatest.

In surface waters where $\mathrm{Si}(\mathrm{OH})_{4}$ concentrations are far below the maximum solubility of opal, temperature is one of the key factors that control the dissolution of amorphous silica. In our study, on an annual time scale, there was no significant correlation between the specific dissolution rate $V_{D}$ and temperature for the Bay of Brest. However, for Period I, a significant correlation, although not strong, was calculated between $\ln \left(V_{D}\right)$ and $\mathrm{T}\left({ }^{\circ} \mathrm{C}\right): \ln \left(V_{D}\right)=0.2898 \mathrm{~T}-9.0221\left(\mathrm{R}^{2}=0.44, \mathrm{~N}=15\right)$. The dissolution $Q_{10}$ is 18.1 , i.e. about 8 times higher than that calculated by Kamatani (1982) and Bidle et al. (2002) for different diatom species, implying a strong temperature dependence of the dissolution rate. Similarly to Kamatani (1982) and Bidle et al. (2002), our experiments for the determination of $\mathrm{BSiO}_{2}$ dissolution were conducted in non-axenic conditions. However, our material came from suspended matter that had been collected in situ, i.e. part of this material should have been grazed before being incubated. As mentioned above, grazing of siliceous material by mesozooplankton could accelerate its dissolution. Clearly, temperature alone cannot explain the dissolution of biogenic silica. The role of bacteria in the control of $\mathrm{BSiO}_{2}$ dissolution, revealed by Bidle \& Azam (1999, 2001) and Bidle et al. $(2002,2003)$, needs further investigation for the Bay of Brest ecosystem.

\section{How does the pelagic dissolution to production ratio in the bay compare to other ecosystems of the world ocean?}

The $D: P$ ratio is used to characterize the fraction of $\mathrm{BSiO}_{2}$ produced that dissolves in surface waters. As most of the published studies took place during productive periods, we decided to limit the comparison to Period I. During Period I, the $D: P$ ratio ranged from 0.19 to 1.27 ; the ratio of the integrated dissolution and production rates was 0.43 , meaning that $43 \%$ of the produced $\mathrm{BSiO}_{2}$ was supplied by regenerated $\mathrm{Si}(\mathrm{OH})_{4}$. The ratio was generally constant during this period, except on June 10 when $D: P$ rose to a very high value (1.27) due to a low production rate (see 'Results'). The data for the beginning of July were also distinguished by ratios $>0.50$. This time period was characterized by 
Table 3. Comparison of production rates $\left(\rho_{P}, \mu \mathrm{mol} \mathrm{l}^{-1} \mathrm{~d}^{-1}\right)$, dissolution rates $\left(\rho_{D}, \mu \mathrm{mol} \mathrm{l}^{-1} \mathrm{~d}^{-1}\right)$ and $D: P$ ratios in surface waters of the world ocean. PFZ: Polar Frontal Zone; WCR: Gulf Stream Warm-Core Ring; ACC: Antarctic Circumpolar Current. F-W: Fall-Winter

\begin{tabular}{|c|c|c|c|c|c|}
\hline Region & Season & $\rho_{P}$ & $\rho_{D}$ & $D: P$ & Source \\
\hline \multicolumn{6}{|l|}{ Oceanic regions } \\
\hline PFZ & F-W 97-98 & 0.31 & 0.08 & 0.26 & Brzezinski et al. (2001) \\
\hline \multirow{2}{*}{ WCR } & Apr-May 82 & 0.11 & & $\leq 0.3$ & Brzezinski \& Nelson (1989) \\
\hline & Jun, 82 & 0.13 & 0.12 & 0.97 & \\
\hline $\mathrm{ACC}$ & Oct 78 & 0.1 & 0.014 & 0.14 & Nelson \& Gordon (1982) \\
\hline \multicolumn{6}{|l|}{ Coastal areas } \\
\hline NW Africa & Apr-May 74 & 0.6 & 0.15 & 0.25 & Nelson \& Goering (1977b) \\
\hline Peru & Mar 76 & & & 0.1 & Nelson et al. (1981) \\
\hline \multirow[t]{2}{*}{ Southern California } & Apr 92 & & & 0.1 & Brzezinski (unpubl. data) in Nelson \\
\hline & Apr 00 & 3 & 0.12 & $<0.05$ & et al. (1995); Brzezinski et al. (2003) \\
\hline Ross Sea & Jan-Feb 90 & 2.0 & 0.3 & 0.15 & Nelson et al. (1991) \\
\hline Amazon & Aug 89 & 6.6 & 2.6 & 0.4 & DeMaster et al. (1996) \\
\hline Bay of Brest & Period I & 0.96 & 0.40 & 0.43 & This study \\
\hline
\end{tabular}

a bloom of Chaetoceros sp. and also by a relative high 'grazing index' (>0.4). In addition to the argument developed in 'Results' (small diatoms settle slowly), these high $D: P$ ratios are characteristic and consistent with the increase in the relative proportion of detrital $\mathrm{BSiO}_{2}$ following bloom events due to cell death and grazing. This can also explain the doubling of the $D: P$ between May 21 and 28.

The mean $D: P$ ratio in surface waters during Period I was compared to data excerpted from publications (Nelson \& Goering 1977b, Nelson \& Gordon 1982, Brzezinski \& Nelson 1989, DeMaster et al. 1996 and Brzezinski et al. 2001). The mean $D: P$ ratio was calculated or reported for surface waters of the Polar Frontal Zone (PFZ), a Gulf Stream Warm-Core Ring (WCR), the Antarctic Circumpolar Current (ACC), the North West Africa upwelling system (NW Africa), the Peru upwelling system, the South California coast, the Ross Sea and the Amazon shelf waters (Table 3).

The PFZ showed a $D: P$ surface ratio of 0.26 . For the Gulf Stream WCR, Brzezinski \& Nelson (1989) mentioned a ratio $\leq 0.30$ during April/May and an average ratio of 0.97 for surface oligotrophic waters in June. This ratio has to be taken as a minimum because of the tracer addition that may have raised production rates (Brzezinski \& Nelson 1989). The average ratio calculated using surface data of the NW Africa upwelling was 0.25 . It appeared more realistic than the 1.0 cited in Nelson et al. (1995), which was representative of the water column and was probably distorted by sediment resuspension. This lower value is consistent with the 0.1 of Southern California and Peru upwelling systems (estimated indirectly) cited in Nelson et al. (1995). Amazon shelf waters presented very different ratios, probably due to the heterogeneity of the material and the high load of suspended particulate silica from rivers (DeMaster et al. 1996); the average ratio calcu- lated was 0.39. The 2 Southern Ocean regions (ACC and Ross Sea) presented equal average ratios of 0.14 , which are lower than those cited in Nelson et al. (1995), meaning that the recycling was more efficient at depths greater than a few metres. It appears that under optimal conditions of light and nutrient concentrations - here Southern Ocean and the upwelling regions - the surface production is almost entirely supported by external inputs and the recycling is very low $(<0.15)$. Inversely, in oligotrophic waters like the Gulf Stream WCR in June, the production seems to be essentially a regenerated production.

In the productive period of our study, the fraction of silica production supported by pelagic regenerated $\mathrm{Si}(\mathrm{OH})_{4}$ was 0.43 , which places the Bay of Brest intermediate between oligotrophic and nutrient-enriched systems. Even at the beginning of the productive period, when nutrients were not limiting, the ratio was 2 times higher than that found in upwellings, indicating higher Si recycling in surface waters. This might be due to a higher grazing pressure and a higher bacterial activity in the Bay of Brest compared to these upwelling oceanic ecosystems.

\section{Conclusions}

Using for the first time an adapted model to better estimate the production and dissolution rates, this study contributes to a better understanding of the silica recycling in pelagic waters. It shows how large the seasonal variations in the production and dissolution rates of biogenic silica are in temperate coastal waters. It illustrates the big differences in specific production rates that exist between species during the productive period, with a higher $V_{P}$ for Chaetoceros sp. than for other diatoms. This study also demonstrates the power 
of high frequency time-series in detecting long-term changes in the functioning of marine ecosystems. It suggests that the summer shift of dominance from diatoms to non-diatoms might be initiated by severe co-limitation conditions (N, P, Si). It also shows that, in spite of high $\mathrm{Si}(\mathrm{OH})_{4}$ concentrations during summer, dinoflagellates are able to outcompete diatoms in low $\mathrm{N}$ and $\mathrm{P}$ nutrient environments. However, further developments are needed to better identify the bottom-up and/or top-down processes that are responsible for the end of this year-round diatom dominance, and to better understand the processes that control the regeneration of $\mathrm{BSiO}_{2}$ in coastal waters.

Acknowledgements. Thanks are due to the SOMLIT-Brest staff of IUEM-FR CNRS 2195 (E. Follenfant, J. Guillou and C. Tartu), and to 4 anonymous referees for their helpful comments. Contribution No. 901 of European Institute for Marine Studies, Brest, France.

\section{LITERATURE CITED}

Beaugrand G, Reid PC, Ibanez F, Lindley JA, Edwards M (2002) Reorganization of North Atlantic marine copepod biodiversity and climate. Science 296:1692-1694

Bidle KD, Azam F (1999) Accelerated dissolution of diatom silica by marine bacterial assemblages. Nature 397: 508-512

Bidle KD, Azam F (2001) Bacterial control of silicon regeneration from diatom detritus: significance of bacterial ectohydrolases and species identity. Limnol Oceanogr 46(7): 1606-1623

Bidle KD, Manganelli M, Azam F (2002) Regulation of oceanic silicon and carbon preservation by temperature control on bacteria. Science 298:1980-1984

Bidle KD, Long RA, Brzezinski MA, Jones J, Azam F (2003) A leak in the oceanic silica pump caused by bacteriamediated silica dissolution. Limnol Oceanogr 48(5): 1855-1868

Billen G, Lancelot C, Meybeck M (1991) N, P, Si retention along the aquatic continuum from land to ocean. In: Mantoura RFC, Martin JM, Wollast R (eds) Ocean margin processes in global change. J Wiley \& Sons, New York, p 19-44

Brzezinski MA (1985) The Si:C:N ratio of marine diatoms: interspecific variability and the effect of some environmental variables. J Phycol 21:347-357

Brzezinski MA, Nelson DM (1989) Seasonal changes in the silicon cycle within a Gulf Stream warm-core ring. DeepSea Res 36:1009-1030

Brzezinski MA, Phillips DR, Chavez FP, Friederich GE, Dugdale RC (1997) Silica production in the Monterey, California upwelling system. Limnol Oceanogr 42: 1694-1705

Brzezinski MA, Nelson DM, Franck VM, Sigmon DE (2001) Silicon dynamics within an intense open-ocean diatom bloom in the Pacific sector of the Southern Ocean. DeepSea Res II 48:3997-4018

Brzezinski MA, Jones J, Bidle K, Azam F (2003) The balance between biogenic silica production and silica dissolution in the sea. Insights from Monterey bay, California applied to the global data set. Limnol Oceanogr 48(5):1846-1854
Buck KR, Bolt PA, Garrison DL (1990) Phagotrophy and fecal pellet production by an athecate dinoflagellate in Antarctic sea ice. Mar Ecol Prog Ser 60:75-84

Buesseler KO (1998) The decoupling of production and particle export in the surface ocean. Global Biogeochem Cycles 12:297-310

Chauvaud L, Jean F, Ragueneau O, Thouzeau G (2000) Long term variation of the Bay of Brest ecosystem: benthicpelagic coupling revisited. Mar Ecol Prog Ser 200:35-48

Conley DJ (2002) Terrestrial ecosystems and the global biogeochemical silica cycle. Global Biogeochem Cycles 16(4):1121

Conley DJ, Schelske CL, Stoermer EF (1993) Modification of the biochemical cycle of silica with eutrophication. Mar Ecol Prog Ser 101:179-192

Del Amo Y, Le Pape O, Tréguer P, Quéguiner B, Ménesguen A, Aminot A (1997a) Impacts of high-nitrate freshwater inputs on macrotidal ecosystems. I. Seasonal evolution of nutrient limitation for the diatom-dominated phytoplankton of the Bay of Brest (France). Mar Ecol Prog Ser 161: 213-224

Del Amo Y, Quéguiner B, Tréguer P, Breton H, Lampert L (1997b) Impacts of high-nitrate freshwater inputs on macrotidal ecosystems. II. Specific role of the silicic acid pump in the year-round dominance of diatoms in the Bay of Brest (France). Mar Ecol Prog Ser 161:225-237

Delmas R (1981) Etude de l'évolution saisonnière des sels nutritifs dans la Rade de Brest en fonction des apports fluviaux et des échanges avec l'Iroise. PhD thesis, Université de Bretagne Occidentale, Brest

DeMaster DJ, Smith WO Jr, Nelson DM, Aller JY (1996) Biogeochemical processes in Amazon shelf waters: chemical distributions and uptake rates of silicon, carbon and nitrogen. Cont Shelf Res 16(5/6):617-643

Dugdale RC, Wilkerson FP (1998) Silicate regulation of new production in the equatorial Pacific upwelling. Nature 391:270-273

Dugdale RC, Wilkerson FP, Minas HJ (1995) The role of the silicate pump in driving new production. Deep-Sea Res I 42:697-719

Egge JK (1998) Are diatoms poor competitors at low phosphate concentrations? J Mar Syst 16:191-198

Elskens M, Baeyens W, Cattaldo T, Dehairs F, Griffiths B (2002) N-uptake conditions during the summer in the subAntarctic and Polar Frontal Zones of the Australian sector of the Southern Ocean. J Geophys Res 107:3-1-3-11

Fisher TR, Peele ER, Ammerman JW, Harding LW Jr (1992) Nutrient limitation of phytoplankton in Chesapeake Bay. Mar Ecol Prog Ser 82:51-63

Hamm CE, Merkel R, Springers O, Jurkojcs P, Maier C, Prechtel K, Smetacek V (2003) Architecture and material properties of diatom shells provide effective mechanical protection. Nature 421:841-843

Howarth RW, Billen G, Swaney D, Townsend A and 11 others (1996) Regional nitrogen budgets and riverine N \& P fluxes for the drainage to the North Atlantic Ocean: natural and human influences. Biogeochemistry 35:75-139

Hurd DC (1972) Factors affecting the solution rate of biogenic opal in seawater. Earth Planet Sci Lett 15:411-417

Hurd DC, Birdwhistell S (1983) On producing a general model for biogenic silica dissolution. Am J Sci 283:1-28

Kamatani A (1982) Dissolution rate of silica from diatoms decomposing at various temperatures. Mar Biol 68:91-96

Kamatani A, Riley JP (1979) Rate of dissolution of diatom silica walls in seawater. Mar Biol 55:29-35

Le Pape O, Del Amo Y, Menesguen A, Aminot A, Quéguiner B, Tréguer P (1996) Resistance of a coastal ecosystem to increasing eutrophic conditions: the Bay of Brest (France), 
a semi-enclosed zone of Western Europe. Cont Shelf Res 16:1885-1907

Lewin JC (1961) The dissolution of silica from diatom walls. Geochim Cosmochim Acta 21:182-195

Lund JWG, Kipling C, Le Cren ED (1958) The inverted microscope method of estimating algal numbers and the statistical basis of estimations by counting. Hydrobiol 11: 143-178

Malej A, Mozetič P, Malačič V, Terzić S, Ahel M (1995) Phytoplankton responses to freshwater inputs in a small semienclosed gulf (Gulf of Trieste, Adriatic Sea). Mar Ecol Prog Ser 120:111-121

Murphy J, Riley JP (1962) A modified single solution method for the determination of phosphate in Natural Waters. Anal Chim Acta 27:31-36

Nelson DM, Dortch Q (1996) Silicic acid depletion and silicon limitation in the plume of the Mississippi River: evidence from kinetic studies in spring and summer. Mar Ecol Prog Ser 136:163-178

Nelson DM, Goering JJ (1977a) A stable isotope tracer method to measure silicic acid uptake by marine phytoplankton. Anal Biochem 78:139-147

Nelson DM, Goering JJ (1977b) Near-surface silica dissolution in the upwelling region off northwest Africa. Deep-Sea Res 24:65-73

Nelson DM, Gordon LI (1982) Production and pelagic dissolution of biogenic silica in the Southern Ocean. Geochim Cosmochim Acta 46:491-500

Nelson DM, Goering JJ, Boisseau W (1981) Consumption and regeneration of silicic acid in three coastal upwelling systems. In: Richards FA (ed) Coastal upwelling. American Geophysical Union, Washington, DC, p 242-256

Nelson DM, Ahern JA, Herlihy LJ (1991) Cycling of biogenic silica within the upper water column of the Ross Sea. Mar Chem 35:461-476

Nelson DM, Treguer P, Brzezinski MA, Leynaert A, Quéguiner B (1995) Production and dissolution of biogenic silica in the ocean: revised global estimates, comparison with regional data and relationship to biogenic sedimentation. Global Biogeochem Cycles 9:352-372

Officer CB, Ryther JH (1980) The possible importance of silicon in marine eutrophication. Mar Ecol Prog Ser 3:83-91

Patrick S, Holding AJ (1985) The effect of bacteria on the solubilization of silica in diatom frustules. J Appl Bacteriol 59:7-16

Quéguiner B (1982) Variations qualitatives et quantitatives du phytoplancton dans un écosystème eutrophe fortement soumis aux effets des marées: la Rade de Brest. PhD thesis, Université de Bretagne Occidentale, Brest

Quéguiner B, Tréguer P (1984) Studies on the phytoplankton in the Bay of Brest (Western Europe). Seasonal variations

Editorial responsibility: Otto Kinne (Editor),

Oldendorf/Luhe, Germany in composition, biomass and production in relation to hydrological and chemical features (1981-1982). Bot Mar 27:449-459

Ragueneau O, Tréguer P (1994) Determination of biogenic silica in coastal waters: applicability and limits of the alkaline digestion method. Mar Chem 45:43-51

Ragueneau O, De Blas Varela E, Tréguer P, Quéguiner B, Del Amo Y (1994) Phytoplankton dynamics in relation to the biogeochemical cycle of silicon in a coastal ecosystem of Western Europe. Mar Ecol Prog Ser 106:157-172

Ragueneau O, Chauvaud L, Leynaert A, Thouzaud G and 8 others (2002) Direct evidence of a biologically active coastal silicate pump: ecological implications. Limnol Oceanogr 47(6):1849-1854

Revelante N, Gilmartin M (1976) The effect of Po river discharge on phytoplankton dynamics in the northern Adriatic Sea. Mar Biol 34:259-271

Revelante N, Gilmartin M (1978) Characteristics of the microplankton and nano-plankton communities of an Australian coastal plain estuary. Aust J Mar Freshw Res 29: 9-18

Riegman R, De Boer M, de Senerpont Domis L (1996) Growth of harmful marine algae in multispecies cultures. J Plankton Res 18:1851-1866

Savoye N (2001) Origine et transfert de la matière organique particulaire dans les écosystèmes littoraux macrotidaux. $\mathrm{PhD}$ thesis, Université de Bretagne Occidentale, Brest

Smayda TJ (1990) Novel and nuisance phytoplankton blooms in the sea: evidence for a global epidemic. In: Graneli E, Sundström B, Edler L, Anderson DM (eds) Toxic marine phytoplankton. Elsevier, Amsterdam, p 29-40

Souchu P (1986) Contribution à l'étude du cycle de l'azote en écosystème macrotidal. $\mathrm{PhD}$ thesis, Université de Bretagne Occidentale, Brest

Tréguer P, Le Corre P (1975) Manuel d'analyse des sels nutritifs dans l'eau de mer. Utilisation de l'Auto-Analyseur II: Technicon, 2nd edn. Laboratoire d'Océanographie Chimique, Université de Bretagne Occidentale, Brest

Tréguer P, Le Corre P (1976) Contribution à l'étude de la matière organique dissoute et des sels nutritifs dans l'eau de mer. Caractéristiques chimiques du Golfe de Gascogne et des upwellings côtiers de l'Afrique du Nord-Ouest. $\mathrm{PhD}$ thesis, Université de Bretagne Occidentale, Brest

Tréguer $\mathrm{P}$, Nelson DM, van Bennekom AJ, DeMaster DJ, Leynaert A, Quéguiner B (1995) The silica balance in the world ocean: a re-estimate. Science 268:375-379

Utermöhl M (1931) Über das umgekehrte Mikroskop. Arch Hydrobiol Beih Ergeb Plankton 22:643-645

Yentsch CS, Menzel DW (1963) A method for the determination of phytoplankton chlorophyll and pheopigment by fluorescence. Deep-Sea Res 10:221-231

Submitted: March 21, 2003; Accepted: September 16, 2003 Proofs received from author(s): February 2, 2004 